\title{
Field Evaluation of Spinetoram 12 SC against Leaf Damage due to Spodoptera litura Fabricius on Onion
}

\author{
A. Sanjeevi Kumar*, N. Muthukrishnan and K. Maruthpandi \\ Department of Agricultural Entomology, Agricultural College and Research Institute, \\ Madurai - 625 104, Tamil Nadu, India \\ *Corresponding author
}

\section{A B S T R A C T}

\begin{tabular}{|l|}
\hline Ke y w o r d s \\
$\begin{array}{l}\text { Spinetoram, Onion, } \\
\text { Field efficacy, } \\
\text { Spodoptera litura, } \\
\text { Yield. }\end{array}$ \\
\hline Article Info \\
\hline $\begin{array}{l}\text { Accepted: } \\
\text { 20 September } 2017 \\
\text { Available Online: } \\
\text { 10 November } 2017\end{array}$ \\
\hline
\end{tabular}

Keywords

Spinetoram, Onion,

Field efficacy,

Spodoptera litura,

20 September 2017

10 November 2017
Spodoptera litura (Noctuidae: Lepidoptera) is a notorious leaf damaging pest in Tamil Nadu in onion and responsible for considerable yield loss. A new biological insecticide spinetoram $12 \mathrm{SC}$ was evaluated for effect on leaf damage due to $S$. litura on onion at field conditions during 2012 and 2013 kharif seasons. Spinetoram $12 \mathrm{SC}$ was applied as foliar spray at 30,36 and $45 \mathrm{~g}$ a.i. $\mathrm{ha}^{-1}$ and compared with emamectin benzoate 5 SG @ $11 \mathrm{~g}$ a.i. ha ${ }^{-1}$, spinosad 45 SC @ $78 \mathrm{~g}$ a.i. ha ${ }^{-1}$, fipronil $80 \mathrm{WG} @ 40 \mathrm{~g}$ a.i. ha $^{-1}$ and thiamethozam $25 \mathrm{WG} @ 62.5 \mathrm{~g}$ a.i. ha $^{-1}$. Results indicated that spinetoram $12 \mathrm{SC}$ was significantly effective at 36 and $45 \mathrm{~g}$ a.i. $\mathrm{ha}^{-1}$ when sprayed thrice at 15 days interval in minimizing leaf damages on onion plants and in increasing the bulb yield. All the spinetoram doses did not show any phytotoxic symptoms on onion plants.

\section{Introduction}

India is the second largest producer of onion, Allium cepa $\mathrm{L}$. in the world after China. It is cultivated in an area of 10.52 lakh hectares in india with an annual production of about 168.13 lakh tonnes. In Tamil Nadu it occupies in area of 0.37 lakh hectares with an annual production of 4.30 lakh tonnes during 201213 (1). Among several factors that limit onion cultivation, insect pests stand foremost in reducing the yield in India and each year about 10 to 25 per cent of the world's total production is lost due to pests attack (2). Young cutworm larvae, Spodoptera litura (F.) feed on tender foliage and grown up larva cut the stem at collar region. The leaf feeder, $S$. litura is a potential polyphagous pest which attack many other crops such as cotton, groundnut, rice, tomato, tobacco, citrus, cocoa, potato, rubber, castor, millets, sorghum, maize etc., in India and cause extensive economic damage (3). Synthetic insecticides provide dramatic effect initially, and hence chemical control methods are still in use among farmers. Earlier, conventional insecticides like endosulfan (4) and (5), malathion and hostathion (6), (7) chlorpyriphos, azadirachtin $1 \%$, phosalone and quinalphos (8), synthetic pyrethroids and endosulfan alternatively with NSKE 4\% (9), and fenvalerate, methomyl, azinphosmethyl, carbaryl and pyrethrin/rotenone (10) were reported in management of pests on onion. 
In recent times, new insecticide molecules offer advantages over earlier chemistry in terms of greater levels of safety, better performance and reduced environmental impact. One such new insecticide molecule is spinetoram, has shown outstanding efficacy against tomato caterpillar (Spodoptera litura Fabricius) (11), shoot and fruit borer (Leucinodes orbonalis Guenee) (12), codling moth (Cydia pomonella L.), oriental fruit moth (Grapholita molesta Busck), army worms (Spodoptera spp), cabbage looper (Trichoplusia ni Hubner), thrips such as western flower thrips (Frankliniella occidentalis Pergande) and onion thrips (Thrips tabaci Lindeman), leaf miners (Liriomyzaspp), chillithrips (Scirtothrips dorsalis Hood), fruit borer (H. armigera) and many other pests (13). However, there are no reports on field evaluation of spinetoram 12 SC against leaf damage due to $S$. litura on onion. Therefore, this study was undertaken with the objectives to investigate field toxicity of spinetoram $12 \mathrm{SC}$ and other insecticides against leaf damage due to $S$. litura on onion during 2012 and 2013 kharif seasons.

\section{Materials and Methods}

Field evaluation of spinetoram $12 \mathrm{SC}$ against leaf damage due to $S$. litura on onion

Two field experiments with onion (cv. CO1) were laid out to evaluate the effect of spinetoram 12 SC against leaf feeder, S. litura on onion plants. The plot size plot size of $5 \mathrm{X}$ $5 \mathrm{~m}$ which occupied 555 number of onion plants TNAU recommended agronomic practices were followed to maintain healthy onion plants throughout experimental period. Spinetoram $12 \mathrm{SC}$ was assessed at $30 \mathrm{~g}$ a.i./ha, $36 \mathrm{~g}$ a.i./ha and $45 \mathrm{~g}$ a.i./ha and compared with emamectin benzoate 5 SG @ $11 \mathrm{~g}$ a.i/ha, spinosad 45 SC @ $78 \mathrm{~g}$ a.i/ha, fipronil 80 WG @ $40 \mathrm{~g}$ a.i/ha, thiamethoxam
25 WG @62.5 g a.i/ha and untreated check (water spray) against leaf damage due to leaf feeder, S. litura. There were three applications at 20 days interval based on ETL of target pests. Thorough coverage of plants (to a run off point) with the spray fluid of 500 1/ha was ensured by using high volume knapsack sprayer with hydraulic cone nozzle. Observations on the total number of healthy leaf and damaged leaf from 10 randomly selected plants per plot were recorded at one day before and on 1, 3, 7 and 10 days after treatment (DAT) after each spray. Marketable bulb yield was recorded after harvests and the bulb yield was represented as quintal/ha. Data obtained were subjected to analysis of variance (ANOVA) after transformation (arc sine for per cent data and square root for population data) of data as per the procedure suggested by (14) and original values are given in Tables. The observations on phytotoxicity symptoms (leaf injury, wilting, vein clearing, necrosis, epinasty and hyponasty) were recorded on $7^{\text {th }}$ day after each spray by using visual scoring system.

\section{Results and Discussion}

Field evaluation of spinetoram 12 SC against leaf damage $S$. litura on onion

Leaf damage due to cutworm ranged from 11.9 to 15.8 per cent per ten plants during first season before imposing treatments and crossed the economic threshold level (ETL) (Table 1). Mean data revealed that leaf damage by cutworm varied from 4.4 to 24.3 per cent per tent plants due to treatments. Significant effect was achieved due to spinetoram 12 SC $45 \mathrm{~g}$ (4.4\%/ten plants with 81.8 per cent reduction). This was on par with spinetoram 12 SC $36 \mathrm{~g}$ (4.7\%/ten plants with 80.6 per cent reduction). Spinosad $45 \mathrm{SC}$ at $78 \mathrm{~g}$ a.i./ha (6.6\%/ten plants with $72.8 \%$ reduction respectively) was the next best treatment. Spinetoram 12 SC $30 \mathrm{~g}$ a.i./ha and 
fipronil $80 \mathrm{WG}$ at $40 \mathrm{~g}$ a.i./ha achieved same level of per cent reduction 7.4 leaf damage per ten plants (69.5\% reduction respectively). Emamectin benzoate $5 \mathrm{SG}$ at $11 \mathrm{~g}$ a.i./ha and thiamethoxam $25 \mathrm{WG}$ at $62.5 \mathrm{~g}$ a.i./ha registered 8.2 (66.2\% reduction respectively) and 10.0 (58.8\% reduction respectively) per cent mean leaf damage per ten plants respectively as against 24.3 per cent mean leaf damage per ten plants in untreated control.

Data pertaining to leaf damage due to $S$. litura during second season for 1, 3, 7 and 10 DAT after three sprays presented in table 1 indicated that mean per cent leaf damage observations of $1,3,7$ and 10 DAT ranged from 4.3 to 22.0 per ten plants due to treatments. Mean per cent leaf damage inferred that spinetoram $12 \mathrm{SC} 45$ and $36 \mathrm{~g}$ a.i./ha were significantly effective in minimizing leaf damage to 4.3 and 4.8 per cent per ten plants and registered 80.4 and 78.1 per cent reduction followed by spinosad $45 \mathrm{SC}$ at $78 \mathrm{~g}$ a.i./ha (5.5\%/ten plants and $75.0 \%$ reduction).

Spinetoram $12 \mathrm{SC} 30 \mathrm{~g}$ a.i./ha (6.2\%/ten plants and $71.8 \%$ reduction), fipronil $80 \mathrm{WG}$ at $40 \mathrm{~g}$ a.i./ha $(6.9 \% /$ ten plants and $68.6 \%$ reduction), emamectin benzoate $5 \mathrm{SG}$ at $11 \mathrm{~g}$ a.i./ha (7.4\%/ten plants and $66.3 \%$ reduction) and thiamethoxam $25 \mathrm{WG}$ at $62.5 \mathrm{~g}$ a.i./ha (8.0\%/ten plants and $63.6 \%$ reduction) however were also moderately effective in minimizing leaf damage.

The present result are in corroboration with the findings of (15) spinetoram $12 \mathrm{SC}$ at $60 \mathrm{~g}$ a.i/ha was highly effective in checking the larval population of $S$. litura during both the years in soybean. The most effective insecticides for army worm (Spodoptera spp) control were spinetoram, spinosad and indoxacarb; the next most effective insecticides were novaluron and metaflumizone; and least effective were pyridalyl (16). (17) spinosad, indoxacarb and pyridalyl significantly reduced beet armyworm ( $S$. exigua) compared to the control. Similar results of effectiveness of spinosad against $S$. exigua in cotton have been documented (18).

\section{Effect of spinetoram $12 \mathrm{SC}$ on bulb yield}

Data on marketable bulb yield ranged from 11.5 to $18.1 \mathrm{t} / \mathrm{ha}$ in first season experiment respectively due to all treatments. There was significant difference due to spinetoram 12 SC applications. Highest bulb yield was recorded due to spinetoram $12 \mathrm{SC} 45 \mathrm{~g}$ a.i./ha (18. $1 \mathrm{t} / \mathrm{ha}$ ) and this was followed by spinetoram 12 SC $36 \mathrm{~g}$ a.i./ha (17.5 t/ha). Spinetoram 12 SC $30 \mathrm{~g}$ a.i./ha, spinosad 45 $\mathrm{SC}$ at $78 \mathrm{~g}$ a.i./ha, fipronil $80 \mathrm{WG}$ at $40 \mathrm{~g}$ a.i./ha and emamectin benzoate $5 \mathrm{SG} 11 \mathrm{~g}$ a.i./ha were the next best treatments, which contributed higher yield of 17.0, 16.7, 15.3 and $15.6 \mathrm{t} / \mathrm{ha}$ respectively. However, thiamethoxam $25 \mathrm{WG}$ at $62.5 \mathrm{~g}$ a.i./ha registered lowest bulb yield of 15.0 t/ha compared to untreated plot which recorded $11.5 \mathrm{t} /$ ha bulb yield (Table 1).

Onion bulb yield ranged from 11.8 to 18.5 t/ha during second season due to treatments. There was significant difference due to spinetoram 12 SC applications. The highest bulb yield was recorded due to spinetoram 12 SC $45 \mathrm{~g}$ a.i./ha (18.5 q/ha) and spinetoram 12 SC $36 \mathrm{~g}$ a.i./ha (18.2 q/ha). They were followed by spinetoram $12 \mathrm{SC} 30 \mathrm{~g}$ a.i./ha and spinosad $45 \mathrm{SC}$ at $78 \mathrm{~g}$ a.i./ha, which contributed moderate yield of 17.9, $17.2 \mathrm{q} / \mathrm{ha}$ respectively. Fipronil $80 \mathrm{WG}$ at $40 \mathrm{~g}$ a.i./ha $(16.1 \mathrm{q} / \mathrm{ha})$ was the next best treatment. However, emamectin benzoate $5 \mathrm{SG}$ at $11 \mathrm{~g}$ a.i./ha and thiamethoxam $25 \mathrm{WG}$ at $62.5 \mathrm{~g}$ a.i./ha registered lower bulb yield of 16.1 and $15.2 \mathrm{q} / \mathrm{ha}$ compared to untreated plot which recorded $9.1 \mathrm{q} /$ ha bulb yield (Table 1 ). 
Table.1 Effect of spinetoram 12 SC against leaf damage by cutworms (S. litura and S. exigua) on onion (2012 and 2013 seasons)

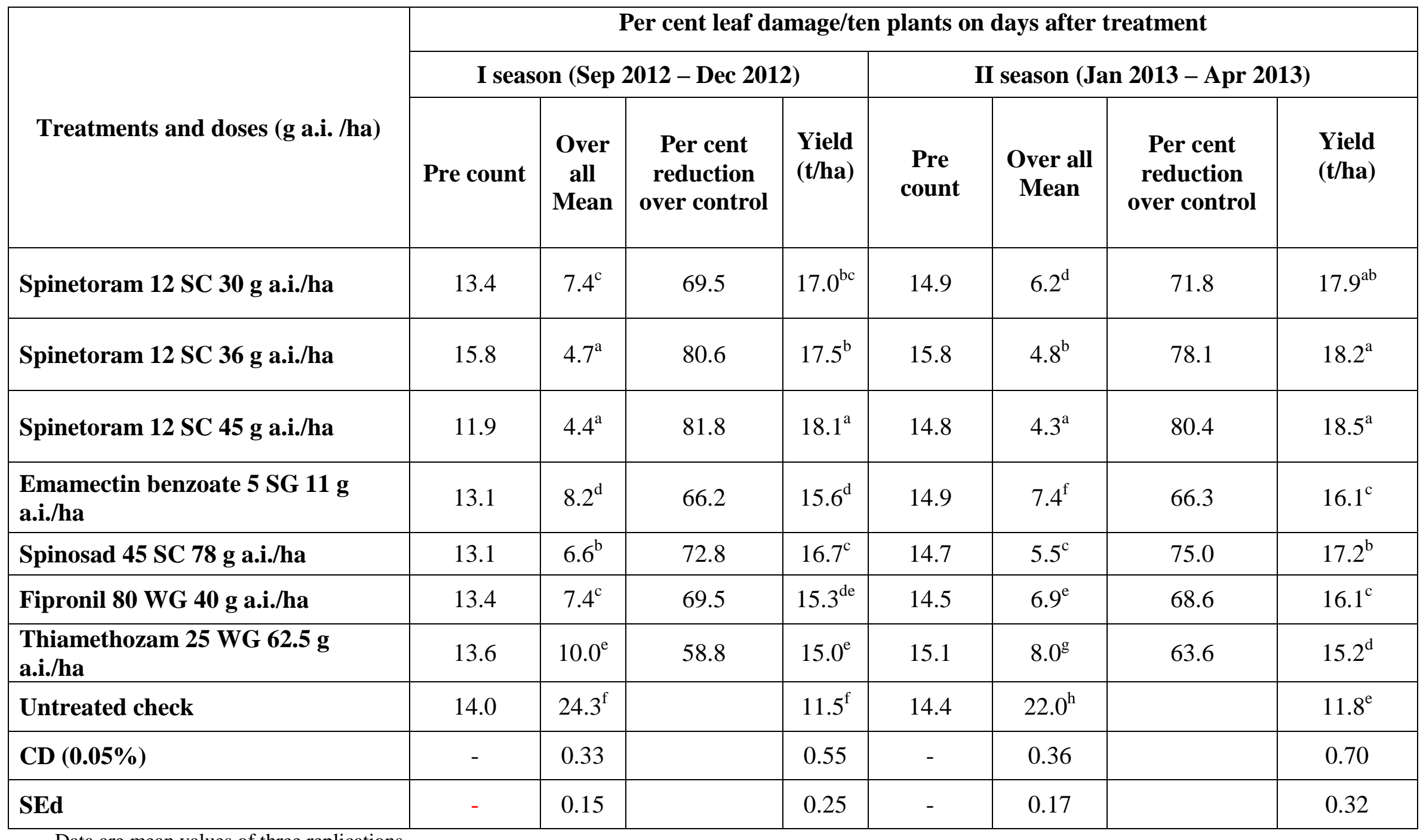

Data are mean values of three replications

Figures were transformed by arc sine transformation and the original values are given

Means within columns lacking common lower case superscript are significantly different $(\mathrm{P}<0.05)$ 
These results are corroborating with the findings of (19) maximum okra fruit yield in spinosad (84 g a.i/ha) treated plots. (20) and (21) effectiveness of spinosad in reducing the fruit infestation and increasing good marketable fruit yield on brinjal. spinosad 45 $\mathrm{SC}$ at $0.1 \%$ was the most effective in reducing the shoot and fruit borer on okra and realized the maximum yield of $84.78 \mathrm{q} / \mathrm{ha}$ (23). (24) spinosad 45 SC recorded lowest mean shoot infestation $(13.7 \%)$, lowest population of whiteflies (6.70/3 leaves), leaf hoppers (5.63/3 leaves) and highest fruit yield (153. 23 $\mathrm{q} \mathrm{ha}^{-1)}$ on brinjal. Spinosad $50 \mathrm{~g}$ a.i/ha recorded the highest protection over control in shoot and fruit infestation and highest fruit yield in brinjal (25).

The overall results on incidence of Spodoptera litura damage and fruit yield revealed that spinetoram $12 \mathrm{SC} 45 \mathrm{~g}$ a.i/ha and spinetoram $12 \mathrm{SC} 36 \mathrm{~g}$ a.i/ha were found to be highly effective against Spodoptera litura and also recorded with the highest fruit yields.

\section{Acknowledgements}

The authors express sincere thanks to Dow Agro Science India Pvt. Ltd, Mumbai for providing financial help during the course of investigations. Authors are also thankful to Tamil Nadu Agricultural University, Coimbatore and Agricultural College and Research Institute, Madurai for granting permission to publish the results.

\section{References}

1. Anonymous. 2013. National Horticultural Board, 2013. http://nhb.gov.in. Indian Horticulture Database, National Horticultural Board, Ministry of Agriculture, Government of India, Gurgaon, India.

2. Diaz-Montano, J., Fuchs, M., Nault, B. A., Fail, J and Shelton, A. M. 2011. Onion thrips (Thysanoptera: Thripidae): A global past of increasing concern in onion. Journal of Economic Entomology 104: 1-13.

3. Vinod Kumari, A and Singh, N. P. 2009. Spodoptera litura nuclear polyhedrosis virus (NPV-S) as a component in Integrated Pest Management (IPM) of Spodoptera litura (Fab.) on cabbage. Journal Biopesticides, 2(1): 84-86.

4. Shivalingaswamy, T. M., Kumar, A., Satpathy, S. and Rai, A. B. 2008.Efficacy of indoxacarb against tomato fruit borer, Helicoverpa armigera Hubner. Pestology, 32(8): 39-41.

5. Rath, L. K. and Mukherjee, S. K. 2009.Field evaluation of some biopesticides alone and in alternation with endosulfan against tomato fruit borer. J. Plant Prot. Environ 6(2): 102104.

6. Sanjeev Kumar, A and Gill, C. K. 2010. Incidence of tomato leaf curl virus in relation to whitefly, Bemisia tabaci (Gennadius) population in different insecticidal treatments on tomato crop. Journal Insect Science, 23(3): 327-331.

7. Kuttalam, S., Vinothkumar,B., Kumaran, N. and Boomathi. N. 2008. Evaluation of bio efficacy of flubendiamide 480 SC against fruit borer Helicoverpa armigerain tomato. Pestology. 32(3): 13-16.

8. Anonymous. 2011. Annual Report: Asian Vegetable Research and Development Center (AVRDC), P.O.42, Shanhua, Taiwan, 741 ROC.

9. Anonymous. 2009. Indian horticulture data base NHB. Ministry of Agriculture, Govt. of India, 154-61.

10. Anonymous. 2012. Dow Crop Science Spinetoram. Technical Bulletin 1-11. (12) Muthukrishnan, N., M. Visnupriya, W. Babyrani and C. Muthuiah. 2013a. Persistence Toxicity and Field Evaluation of Spinetoram 12 SC against Shoot and Fruit borer, Leucinodes orbonalis Guenee in Brinjal. Madras Agric. J., 100(4-6): 605-608.

11. Muthukrishnan, N., M. Visnupriya, W. Babyrani and C. Muthuiah. 2013a. In-vivo and Field Evaluation of Spinetoram 12 SC against Spodoptera litura Fabricius on Tomato. Madras Agric. J., 100(4-6): 601604. 
12. Muthukrishnan, N., M. Visnupriya, W. Babyrani and C. Muthuiah. 2013b. In-vivo and Field Evaluation of Spinetoram 12 SC against Leucinodes orbonalis Guenee on Brinjal. Madras Agric. J., 101(4-6): 607-609.

13. Dharne, P. K. and A. S. Bagde. 2011. Bio efficacy of novel insecticide, spinetoram 12 SC $(11.7 \mathrm{w} / \mathrm{w})$ against thrips, Scirtothrips dorsalis Hood and fruit borer, Helicoverpa armigera HB in chilli. Pestology, 35(3): 2326.

14. Gomez, K. A. and A. A. Gomez. 1984. Statistical procedures for Agricultural Research. A Wiley International Science Publication, John Wiley and Sons, New Delhi. 680p.

15. Sanjeev Kumar and Gill, C. K. 2010. Incidence of tomato leaf curl virus in relation to whitefly, Bemisia tabaci (Gennadius) population in different insecticidal treatments on tomato crop.J. Insect Sci, 23(3): 327-331.

16. Dakshina, S. R., Schuster, J. D and Klassen, W. 2007. Comparative effectiveness of new insecticides in controlling armyworms (Lepidoptera: Noctuidae) and leafminers (Diptera: Agromyzidae) on tomato. Proceeding Fla State Horticultural Society, 120: 170-177.

17. Cook, D. R, Leonard, B. R and Gore, J. 2004. Field and laboratory performance of novel insecticides against armyworms (Lepidoptera: $\quad$ Noctuidae). $\quad$ Florida Entomologist, 87(4): 433-439.

18. Halcomb, J. L., Benedict, J. H and Correa, J. C. 1998. A field study to evaluate the efficacy of selected insecticides against beetworm on transgenic cotton. In
"Arthropod Management Tests", Entomol. Soc. Amer. Lanham, MD. p 229-230.

19. Amalendu, G., C. Monilal and A. Roy. 2011. Bio-efficacy of spinosad against tomato fruit borer (Helicoverpa armigera Hub.) (Lepidoptera: Noctuidae) and its natural enemies. J. Horti. \& Forestry, 2(5): 108-111.

20. Sinha, S. R. and V. Nath. 2011a. Management of Leucinodes orbonalis through insecticides in brinjal. Ann. Pl. Protec. Sci., 17(2): 328-331.

21. Wankhede, S. M. and V. D. Kale. 2010. Effect of insecticides on Leucinodes orbonalis. Ann. Pl. Protec. Sci., 18: 336-339.

22. Singh, B. K. and R. P. Gupta. 2011. Efficacy of some bio-pesticides for the management of shoot \& fruit borer (Earias vittella Fabricius) infesting okra. Pestology, 35(5): 30-31.

23. Biswas, K., S. Mallikarjunappa and U. G. Bhat. 2009. Takumi - An ultimate new generation product for the management of most problematic insect pest, shoot and fruit borer, Leucinodes orbonalis (Guen) of brinjal. Pestology, 33(10): 23- 25.

24. Pareet, J. D. and K. Basavanagoud. 2012. Use of bio pesticides against Leucinodes orbonalis Guen. infestation and yield in brinjal. Ann. Pl. Protec. Sci., 20(1): 79-82.

25. Anandkumar, V., A. Nagangoud and B. V. Patil. 2002. Management of brinjal shoot and fruit borer, Leucinodes orbonalis (Guen.). In: Proc National Seminar on "Integrated Pest Management in the current century", November, 29-30, Department of Agricultural Entomology, B.C.K.V., West Bengal, India, p 238-248.

\section{How to cite this article:}

Sanjeevi Kumar, A., N. Muthukrishnan and Maruthpandi, K. 2017. Field Evaluation of Spinetoram 12 SC against Leaf Damage due to Spodoptera litura Fabricius on Onion. Int.J.Curr.Microbiol.App.Sci. 6(11): 2824-2829. doi: https://doi.org/10.20546/ijcmas.2017.611.333 